\title{
SISTEM ANALIZININ TEMELLERI
}

\author{
Doç. Dr. Halil SARLASLAN \\ SBF. İşletme Bölūmü
}

\section{Sistem Kavram}

Çok değişik biçimlerde algılanan sistem analizi kavramının gerçekte neyi ifade ettiğini açılamadan önce bu kavramm özünü oluşturan "sistem" sözcüğünün tanimlanması ve içeriğinin açıklığa kavuşturulması uygun olacaktır. Çünkü sistem sözcüğü de çok değişik bìçimlerde yaygun olarak kullanılmaktadır. Örneğin, uzay sistemi, ekonomi sistemi, politik sistem, yönetim sistemi, işletme sistemi, okul sistemi, sınav sistemi v.b. kavramlan hepimiz günlük yaşamımızda sık sik kullanmakta ya da duymaktaynz.

En açık bir ifade ile sistem, belli bir amacı gerçekleştirmek için birlikte çalışan ve birbirlerini etkileyen parçalardan oluşan bir bütündür. ${ }^{1} \mathrm{Bu}$ tanıma dayalı olarak bir sistemin iki temel özelliğini şöyle belirtebiliriz.

1. Bir Amacı Olmak : Her sistemin gerçekleştirmek istediği belli bir amacı ya da amaçları vardır. Herhangi bir amacı olmayan bütünü sistem olarak adlandurmak olası değildir. Başka bir anlatımla bir sistemin var olmasinin nedeni bir amacinin bulunmasidır.

2. Birbirleri ile Etkileşimde Bulunan Parçalardan Oluşmak: Sịstemi bir bütün olarak oluşturan parçalar amacı gerçekleştirmek için birlikte çalışırlar ve çalışma sırasında birbirleri ile etkileşimde bulunurlar. Bu etkileşim sistemin önemli bir özelliğidir ve sistemi bir "parçalar yığını" olmaktan kurtanr. Parçalardan birisinde meydana gelen, bir değişme sistemin işleyiş̧ini etkiler.

Örneğin, insan vücudu bir sistemdir. Çünkü bir amacı vardur (yaşamak). Çeşitli parçalardan (organlardan) oluşmuştur ve bu parçalar birbirleri ile etkileşim halindedir. Birisinde meydana gelen bir değişme tüm vücudu etkiler. Aynı biçimde işletmede bir sistemdir. Bir ama-

1 Churchman, West C., The Systems Approach, (New York, N.Y.: Dell Publishing Co., Inc., 1968), s. 2830. 
c1 vardır (mal veya hizmet üretmek ya da kâr etmek). Çeşitli parçalardan oluşmuştur (üretim, finansman, personel, muhasebe bölümleri v.b.). Birisindeki değişme tüm sistemi etkiler.

Kuşkusuz, sistem gibi sistemin parçaları ya da diğer adı ile bileșenleri de aynı biçimde çeşitli parçalardan oluşabilirler. Bu tür parçalarn oluşturduğu bütüne ise alt sistem adı verilir. Örneğin bir işletmeyi oluşturan üretim bölümü bir alt sistem olup tedarik, imalat, paketleme v.b. parçalardan oluşur. Dolayısiyle karmaşılklı düzeyine bağlı olarak bir sistem çeşitli parçalardan oluşan değişik sayıda alt sistemlerden oluşabilir. Aynı biçimde bir sistem çeşitli alt sistemlerden oluşacağ gibi kendisi de bir başka sistemin alt sistemi olabilir. Örneğin, bir işletme işletmenin bulunduğu sektọrün alt sistemi, bu sektörde ekonomik sistemin alt sistemini olustururken ekonomik sistemde o ülkenin devlet sistemini oluşturur.

$\mathrm{Bu}$ düşünceden hareketle sistemleri en basitten en genele (karma\$ı̆̆a) doğru karmaşıklık düzeylerine göre hiyerarşik bir düzen içinde sıralamak olasıdır. Bu hiyerarşik sistem düzeni içinde en tepede bulunan en genel ve karmaşı sisteme "süper" ya da "supra" sistem adı verilir.

Hiyerarşik sistem düzeni içinde bir bütün olan her sistem kendisini çevreleyen ve işleyişini sinırlayan diğer sistemlerle yani çevresi ile ilişkide bulunmak zorundadır. Çevresi ile ilişkide bulunmayan sistemlere "kapalı sistemler" adı verilir ki bu tür sistemler sayılan çok az olan mekanik sistemlerdir. Örneğin, termostat ve çalar saat bu tür sistemlere örnek olarak verilebilir. Çevresi ile ilişkide bulunan sistemler "açık sistem" olarak adlandırılırlar." Açık sistemler çevre sistemlerden girdiler alırlar ve bunları belli bir işleme tabi tutarak diğer sistemler için girdi olan bir çıktı üretirler. Bazı sistemler ürettiklerı çıktının bir kısmını kendileri için tekrar bir girdi olarak kullanırlar. Sistemler çıktılarına ilişkin olarak elde edecekleri bilgilere göre kendi işleyişlerindeki hatalan düzelterek (self-correction) istikrarlı bir gelişme dengesi (homeostasis) sağlarlar ki bu tür bilgi akımına "geri besleme (feed-back)" adı verilir.,

Bertalanffy, von L. "The Theory of Open Systems in Physics and Biology" in Systems Thinking, ed., F.E. Emery, (Middlesex: Penguin Books Ltd., 1069) s. 70-71.

3 Katz, D. and Kahn, R.L., "Common Characteristics of Open Systems" in Systems Thinking, ed. F.E. Emery, s. 92-89.

- Optner, Stanford L. Systems Analysis for Business Management, (Englewood Cliffs, N.J. : Prentice-Hall, Inc., 1960), s. 10-17. 
Böylece bir sistemin işleyişi aşağıdaki gibi modelleştirilebilir:

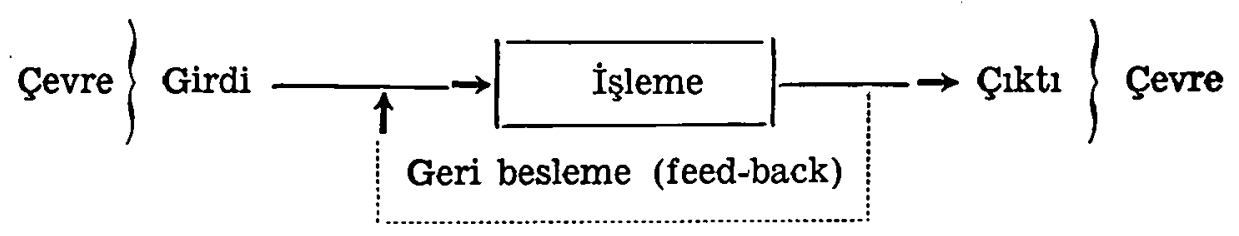

\section{Sistem Yaklaşımı}

Sistem kavramının açıklanılan bu temel içeriğine dayalı bir yaklaşımla evrende varolan çeşitli sistemleri belirlemek ve çevresi ile olan ilişsilerle birlikte bir bütün olarak incelemek bilim adamlan ve araştırmacılar için büyük bir kolaylık sağlayacaktır. Çünkü sistem kavramı çerçevesinde bütünlük ve etkileşim ilkesine dayalı bir yaklaşım ya da en çok bilinen bir ifade ile "Sistem Yaklaşım"; insanların çevrelerindeki olgu ve faaliyetleri birbirleri ile ilişkilendirmesine, bu ilişkilerin hiyerarşik bir düzen biçiminde belirlenip sınıflandırlarak birer sistem çerçevesine konulmasına ve böylece çevredeki karmaşlk olaylardan bir anlam çıkarmasına yardımcı olan bir düşünce biçimi geliştirmesine katkıda bulunacaktır.

Bu düşünce biçimi literatürde "Sistem Kuramı" ya da "Genel Sistem Kuramı (Teorisi)" olarak adlandımlır ve biraz önce belirtildiği gibi temel amacl; dünyadaki genel ilişkileri açlklamak için sistematik ve kuramsal bir çerçeve geliştirmektir. ${ }^{5}$ Bu kurama göre bir sistemler hiyerarşisi olan dünyamızdaki oluşumları bir bütün olarak birbirine ilişkilendirmek olası olduğu gibi bu oluşumları ayrı ayrı açıklamaya çalışan bilim alanlarının tümünü, anlamlı bir iliş̧i çerçevesinde birbirine bağlayacak genel bir kuram geliştirmek de olasıdır. ${ }^{6}$

Sistem Yaklaşımı ya da onun bir uzantısı olan sistem kuramı örgütleri düzenlemek ve yönetmek için de kullanılabilir. Kuramdan uygulamaya inilen bu aşamada amaç, örgütü oluşturan bileşenleri birbirleri ile ilişkilendirmek ve her birinin bir sistem olan örgütün amaçlarını gerçekleştirmede katkısını belirlemektir. Böylece, örgütün işleyişi, bileşenlerinin bütüne katkısı ve aralarındaki ilişkiler ayrı ayrı belirlendikten sonra örgüt amaçlarının en etkin bir biçimde gerçekleştirilmesi için bileşenlerin birbirleri ile yeniden ilişkilendirilmesi, belirle-

5 Johnson, R.A., Kast, F.E. and Rosenzweig, J.E., "Systems Theory and Management.",Management Science, vol. 10 (1964), s. 367-370.

- A.g.e. 
nen ilişkilerin bir bütün olarak düzenlenmesi ve böylece örgütün amą̧larına ulaşması için yönlendirilmesi olası olacaktır.

Sistem yaklaşımının örgütlerde bu tür uygulaması "Sistem İşletmeciliği ya da Yönetimi (Systems Management)" olarak adlandirilur." Görüldüğğü gibi sistem yönetiminin geleneksel yönetim kuramlarından telmel farkı; örgüt yapısının bir sistem olarak amaçları çerçevesinde belirlenmesi ve örgüt bileşenlerinin aym işlevsel birimler olarak değil, örgüt amaçlanna olan katkılan çerçevesinde birbirleri ile ilişkili olarak düzenlenmesidir. Dolayısiyle sistem yönetimi, yönetimin planlama, örgütleme, kadrolama, denetim, v.b. işlevlerini ortadan kalduramaz. Ancak bu işlevlerin, amaçlarını daha etkin (efficient) bir biçimde gerçekleştirecek bïr sistemin düzenlenmesi için bir çerçeve içinde birbirleri ile ilişkilendirilmesini vurgular. ${ }^{8}$

Sistem yaklaşımının kuramdan uygulamaya indirgendiği sistem yönetimi ilkelerine göre bir sistemin düzenlenmesi ve amaçlarının daha etkin bir biçimde gerçekleştirmeye yönlendirilmesi sırasında uygulamada karşılaşlan sorunları çözmek ve daha etkin bir sistem geliştirmek için çeşitli araştırma faaliyetlerinde bulunmak gerekir.

İște daha etkin bir sistem geliştirmek ve yönetimde karşlaşlan sorunları çözmek için yapılması gerekli olan problem çözme ve araştırma çalışmalarının tümü "sistem analizi" olarak adlandırılmaktadır." Başka bir anlatımla, sistem analizi bir örgüt ya da sistem içindeki etkileşim ağının incelenmesi ve sistemin amaçlarını daha etkin olarak gerçekleştirmesi için yeni ve daha iyi yöntemlerin araştırılması ve geliştirilmesi sürecidir. ${ }^{10} \mathrm{Bu}$ nedenle çoğu araştırmacılar tarafından Quade'ın tanımı genel bir kabul görmüştür. Buna göre sistem analizi, amaçları ve bu amaçları gerçekleştirecek seçenek politika ve yöntemleri inceleyerek onlarm ekonomik maliyetlerini, etkililiklerini ve faydalarını riskleri ile birlikte kantitatif olarak karşılaştırmak suretiyle karar vericilere gelecekteki eylem biçimini seçmede yardımcı olan bir araştırma biçimidir. ${ }^{11}$ Böylece sistem analizi bir yöntem ya da teknik

7 Johnson, Richard, A., Roger, W.C. and Newell, J., Operations Management-A Systems Concept. (Boston: Houghton Mifflin Co., 1972), s. 503.

${ }^{8}$ Johnson, Kast ond Rosenzweig, a.g.e., s. 291-298.

- Johinson, Roger and Newell, a.g.e., 502.

10 Semprevivo, Philip C., Systems Analysis: Definition, Process and Design, (Chicago: Science Research Associates, Inc. 1976), s. 7.

11 Quade, E.S. and Boucher, W.I. (eds.), Systems Analysis and Policy Planning, (New York: American Elsevier Publishing Co., Inc., 1968), s. 4.

Fisher, Gene H., Cost Considerations in Systems Analysis, (Now York: American Elsevier Publishing Co., Inc., 1971), s. 6. 
olmaktan çok bir araştırma stratejisidir ve bir seçim gerektiren karmaşık problemlere bï yaklaşım biçimi olarak görülür. ${ }^{12}$

Dolayısiye, şimdiye kadar yapılan açıklamalara dayalı olarak denilebilir ki, sistem yaklaşımı kuramdan uygulamaya ve uygulamada karşılaşllan problemleri çözmeye kadar genelden özele doğru uzanan oldukça geniş bir alanı kapsamaktadır. Sistem analizi de bu alanın son halkasını oluşturmaktadır. Kuşkusuz bu, aynı biçimde genel sistem kuramı, sistem yönetimi ve sistem analizi kavramlarının sistem yaklaşımı adı altında toplandığını da ifade etmektedir. ${ }^{13}$ Yani sistem yaklaşımı bu kavramların hepsini kapsayan genel bir terimdir denilebilir.

\section{Sistem Analizi}

Sistem analizinin özünü ve dayandiğı temel kavramlar olan; sistem, sistem yaklaşımi, genel sistem kurami ve sistem yönetimi kavramları böylece açıklandıktan sonra bir araştirma ve problem çözme yaklaşımı olan sistem analizinin yönetimindeki yeri ve öneminin açıklanması gerekir.

Bilindiği gibi en genel tanımı ile yönetim, örgüt amaçlarının gerçekleştirilmesi için yapllan faaliyetlerin tümüdür. $\mathrm{Bu}$ faaliyetlerin ağırlık merkezini ise karar verme süreci oluşturur. Çünkü hangi faaliyetlerin nerede, ne zaman ve nasıl yapılması gerektiğinin bir karara dayandurlması gerekir. Bu nedenle yöneticiler aslinda karar vericidirler. $\mathrm{Bu}$ açıdan bakıldığında örgütlerin yönetiminde sistem analizi sağlıklı kararlarnn alınmasında ve karşlaşlan problemlerin çözümünde büyük bir yarar sağlayacaktır.

Çünkü sistem analizi, daha önce belirtildiği gibï karar vericilere amaçlarının belirlenmesinde, amaçları gerçekleştirecek olası seçeneklerin sistematik olarak toplam sistem açısından incelenmesi ve değerlendirilmesinde ve böylece izleyecekleri en uygun yolun (eylem biçiminin) seçiminde yardımcı olan bir araştırma ve problem çözme yaklașimidir.

Karar sürecinde böyle bir yaklaşımm izlenmesi yönetimin örgüt amaçlarını daha iyi bir biçimde gerçekleştirmesini ve sonuç olarak da daha etkin bir biçimde işleyen bir sistem geliştirmesini sağlayacaktır.

12 Fisher, a.g.e. s. 10.

Rudwick, Bernard H., Systems Analysis for Effective Planning, (New York : John Wiley and Sons, Inc., 1969), s. 2-5.

13 Johnson, Roger and Newell, a.g.e. s. 502 ve 511. 
Biraz önce verilen tanımdaki sistem analizi çerçevesi anımsanacağı gibi geleneksel karar sürecinde izlenen çerçeve ya da problem çözmede izlenen bilimsel yöntemin hemen hemen aynısıdur. Çünkü bilindiği gibi bu iki yöntem de benzer biçimde amaçların belirlenmesini bu amaçlan gerçekleştirecek çeşitli seçeneklerin araştırılmasını ve en uygun seçeneğin seçilmesini kapsar. Ancak sistem analizi bu genel çerçeve içinde kalmakla birlikte sistem kavramının etkileşim ve bütünlük ilkesine dayalı olarak faaliyetlerin birbirleri ile ilişkili yani sistematik bir biçimde örgüt ya da sistem amaçları açısından değerlendirilmesini vurgular. Bu nedenle daha kapsamlı ve ussal bir araştırma ve problem çörme yaklaşımıdır.

Bunu daha iyi görebilmek için bir sistem analizinin izlediği olası aşamaları Şekil 1'de belirtildiği gibi ana hatları ile incelemek uygun olacaktır. Bir sistem analizi, şekilde belirtildiği gibi, genel olarak şu aşamaları izler: ${ }^{14}$

1. Sistemin Çözümlenmesi : Bu aşama aşağıdaki faaliyetleri kapsar :

a) Sistem İşleyişinin Gözlenmesi :

b) Sistemin Çevresinin Belirlenmesi : Bu aşamada sistemi hangi sistemlerin çevrelediği ve bu sistemlerle ilişkisinin ne olduğu belirlenecektir. Bunun için sistemin çevreden hangi girdiler aldığı, nasıl işlediği ve hangi çıtıtları verdiği saptanır. Ayrıca çevreden gelen ve sistem işleyişini sınırlayan kısitlamaların olup olmadığı da araştınlmahıdır. Örneğin, "yasal sistem" uyulması gereken bazı kısitlamalar koyabilir.

c) Sistemi Oluşturan Bileşenlerin (Altsistemlerin) Belirlenmesi : Amaç bileşenlerin sistem amaçlarının gerçekleşmesine olan katkıları açısından belirlenmesidir.

d) Bileşenler Arasındaki İlişkinin Belirlenmesi : Belirlenen bileşenlerin birbirleri ile nasıl bir alış-verişte bulundukları saptanır. Yani hangi bileşen hangi bileşenlerle ne için ve nassll ilişkide bulunuyor? Girdi olarak ne alıyor ve çlktı olarak ne veriyor? $\mathrm{Bu}$ sorularin yanitlanması gerekir.

e) Verilerin Toplanması, İşlenmesi ve Yorumlanması : Sistemin kendi iç işleyişine ve çevresine ilişkin olarak açık bilgilere sa-

${ }^{14}$ Bundan önceki dipnotlarda belirtilen eserlere dayalı olarak geliştirilmiştir. 


\section{- Sistem ANALIZİ ASAMALARI}

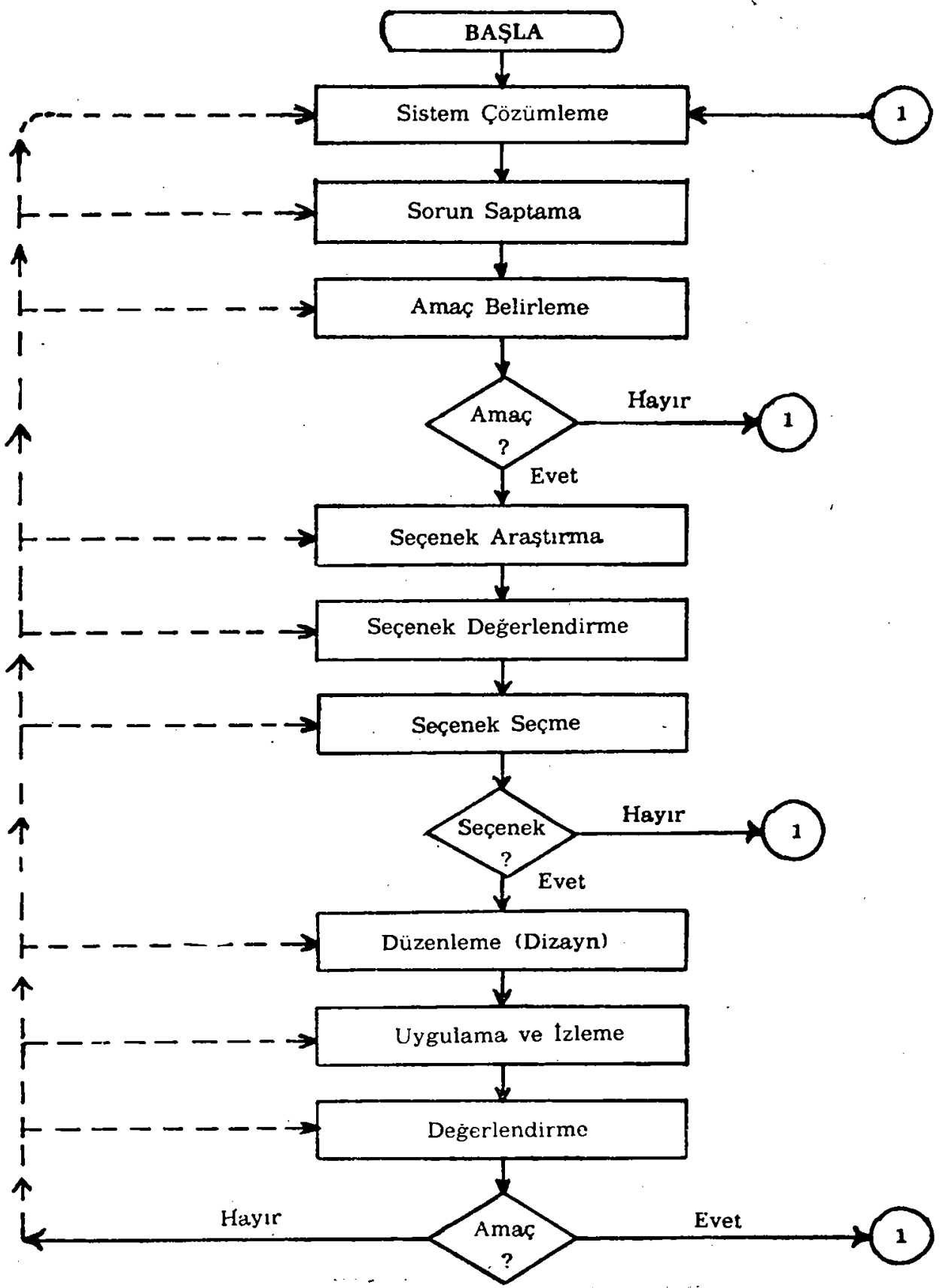


hip olmak için gerekli verilerin toplanması, işlenmesi ve yorumlanmasi gerekir.

2. Sorunun Saptanması : Sistem çözümlenmesi aşamasında işleyişi açık bir biçimde incelenen sistemin istenilen biçimde işleyip işlemediği görülebilecektir. İste bu aşamada sistemin işleyişi sırasında görülen sorunların açık bir biçimde saptanması gerekmektedir. Ancak sorunların genel ifadelerden çok anlaşlabilir problemler biçiminde belirlenmesi gerekir. Eğer sistemin istenilen işleyişi hakkında açık seçik bilgiler varsa problemin bir "gereksinme değerlendirmesi" biçiminde ifade edilmesi çok daha uygun olacaktır. Bu anlamda gereksinme mevcut durum ile olması arzu edilen durum arasındaki boşluğu ifade eder. Böylece sorunun daha anlaşlabilir ve açık bir biçimde ifadesi mümkün olacaktır.

3. Amaçlarin Belirlenmesi : Belirlenen sorun ya da sorunlar, bunların giderilmesini gerektiren bazi amaçları da beraberinde getirecektir. Sistem işleyişinin istenilen duruma getirilmesini vurgulayan bu amaçların belirlenmesi zorunludur. Ancak bu yapılırken şu kurallara uyulmalıdır. Amaçlar:

a) Açık ve Ölçülebilir Olmalı : Bu özellik sistem hedefinin açık bir biçim almasını sağlayacağı gibi, amaçların ne derece gerçekleştiğini belirleme faaliyetlerinde de bir karşlaş̧ırma ölçütü olacaktır. Bu nedenle amaçların ölçülebilir bir biçimde ölçütler olarak belirlenmesi bir sistem analizi için zorunludur. Aksi durumda araştırma, bir sistem analizinden çok sübjektif bir değerlendirme olacaktır ki bu da kavramin özüne uygun düşmez.

b) Anlaşlabilir ve Uyumlu Olmalı : Ölçülebilir amaçlar her yöneticinin anlayabileceği bir biçimde açık olmall, birbirleri ve sistem politikası ile uyumlu olmalıdır.

c) Gerçekçi ve Ulaşlabilir Olmalı : Amaçlar sistemin kaynaklan ve olanakları ölçüsünde gerçekçi olmalıdır. Bu nedenle sistemin kısıtlamaları ve kaynakları ölçüsünde ulaşılabilir olmalidur.

Amaçlar böylece belirlenđikten sonra "Amaçlar sisteme yön gösterebilecek uygunluğa sahip mi?" sorusuna yanıt verilmelidir. Eğer yanit "hayır" ise tekrar başa dönüp gerekenler yapılmalıdır. Kuşkusuz bu, yanit "evet" oluncaya kadar devam etmelidir.

4. Seçeneklerin Araştınlması : Belirlenen uygun amaçlan gerçekleştirebilecek seçenek yolların ve bu yollara ilişkin veri ve bilgilerin 
araştırılması gerekir. $\mathrm{Bu}$ araştırmada analist, araştırma kapsamının ne yürütülemeyecek kadar geniş ne de ciddi olmayacak kadar küçük olmasına dikkat etmelidir. Bunun sinurı analistin yargısına bağlıdır. Ancak araştırma konusu yapılan her seçeneğe ilişkin veri ve bilginin sağlanması zorunludur.

5. Seçeneklerin Değerlendirilmesi : Bu aşamada araştırlan olası seçeneklerin, amaçları gerçekleştirmeleri açısından değerlendirilmesi gerekir. Bunun için her seçeneğin sonuçlarının ve örgüt işleyişi üzerindeki etkilerinin sistematik olarak değerlendirilmesi gerekir. Başka bïr ifade ile, seçeneklerin amaçları gerçekleştirme bakımından değerlendirilmesi yeterli değildir. Seçeneklerin ayni zamanda sistem işleyişint hangi yönde ve nasıl etkilediği de değerlendirilmelidir. Böylece seçeneklerin beklenilmeyen sorunlar yaratması önemli derecede önceden kestirilmiş olunabilir.

$\mathrm{Bu}$ tür bir değerlendirme yapabilmek için sistemin bir modelini geliştirmek zorunlu olmaktadır. Bu nedenle sistem analizi ve model kurma birbirinden ayrilmaz kavramlar olmaktadırlar. ${ }^{15}$ Böylece gerçek sistemin işleyişini temsil eden bir model üzerinde sistemin gerçek işleyişine müdahale edilmeden her seçeneğin toplam sonuçlarn ve etkilerini kestirmek ve değerlendirmek olası olacaktır.

Bu nedenle sistem analizi özellikle bu aşamada kapısını tüm nicel çözümleme teknik ve yöntemlerine açmaktadır. Gerçekte bu gün, sistem analizi yeni yöntem ve tekniklerin gelişimini hızlandırdığı gibi ekonomi, yönetim bilimi (Management Science), mühendislik, matematik, istatistik ve yöneylem araştırması gibi disiplinlerde kullanulan nicel çözümleme yöntemlerini kapsamına almıs ve bunları bir dereceye kadar da birbirleri ile ilişkilendirmiştir. Çünkü model kurma bunu gerektirir.

6. En Uygun Seçeneğin Seçilmesi : Seçenek değerlendirme aşamasında bir modele dayalı olarak elde edilen bilgiler çerçevesinde sistemin amaçlar ve kısıtlamalan göz önünde bulundurularak en uygun (optimal) seçenek seçilir. Ancak seçilen seçeneğin toplam sistem açısundan uygunluğu tekrar değerlendirilmelidir ve "Toplam sistem açısından seçilen seçenek uygun mu?" sorusuna "evet" yanitı alınmalıdur. Aksi durumda tekrar ilk aşamaya dönülecek ve gerekli işlemler yanit olumlu oluncaya kadar devam edecektir.

15 McMillan, Claude and Gonzalez, Richard, F., Systoms Analysis, A Computer Approach to Decision Models, Third Ed. (Homewood, Ill.: Richard D. Irwin, Inc., 1873), s. 6. 
7. Düzènleme (Dizayn) : Seçilen seçeneğin uygulamaya konulabilmesi için uygulama öncesi uygulama ve sonrasında gerekli faaliyetlerin belirlenmesi ve bunlarnn sistemin diğer faaliyetleri ile ilişkilendirilmesi için gerekli olan düzenlemeler planlanmalıdır. PERT ve CPM gibi şebeke analizi teknikleri bu amaç için büyük bir öneme sahiptirler.

8. Uygulama ve İzleme (Monitoring) : Bir önceki aşamada hazarlanan plan çerçevesinde seçilen seçeneğin gerektirdiği faaliyetler uygulamaya konulur. Uygulama sırasında sistemin işleyişinin izlenmesi gerekir. Sistemin izlenmesi, sistemin planlandığı biçimde işleyip işlemediğini belirlemek için yapllmak zorundadır.

İzleme sistemin işleyiş surasında kendi kendini düzeltme olanağ1 sağlar. Çünkü uygulama sırasında ortaya çıkabilecek olan aksaklıklar hemen görülür ve anunda düzeltilmeye gidilir. Böylece sistem kendi kendini düzenleyerek işleyişine devam eder.

9. Genel Değerlendirme : Uygulama sonunda sonuçların ve sistemin başarı durumunun değerlendirilmesi gerekir. Bu nedenle bu aşamada daha önce belirlenmiş olan amaçlara ve ölçütlere dayalı olarak sistemin amaçlarını ne derece gerçekleştirmiş olduğu saptanır.

Başka bir anlatımla uygulamanın başarılı olması yeterli değildir. Önemli olan bu yeni uygulama sonucunda sistemin amaçlarını gerçekleştirip gerçekleştirmediğidir. Bu nedenle değerlendirme süreklilik gösteren ve bir sistemin belirlenen amaçlarına ulaşma derecesini ölçen bir süreçtir. Bu süreç süresince "Sistem Amaçlarını Gẹçekleştiriyor mu?" sorusuna yanıt aranmalıdır. Eğer yanıt "evet" ise, çözümlerin yeni sorunlar ortaya çıkarıp çıkarmadığı ve sistem işleyişinin etkililiğini gözlemek için tekrar analiz aşamasının baş tarafina (1. nolu akıs okunun gösterdiği gibi) dönülmelidir. Eğer yanıt "hayır" ise, "neden?" sorusu sorulacaktır. Amacın neden gerçekleşmediği biliniyorsa hangi aşamada çözüm gerekiyorsa o aşamada gerekli önlemier alınmalıdır. Eğer amaçların neden gerçekleşmediği bilinmiyor ise tekrar başa dönüp analiz süreci tekrarlanacaktır.

\section{Sistem Analizinin Yönetimdeki Önemi}

Bundan önceki sayfalarda kapsamını ve izlediği aşamaları açıladiğımız sistem analizinin yönetim için karar verme sürecinde vazgeçilmez bir yaklaşım olacağı açıktır. Görüldüğü gibi bu yaklaşımın diğer geleneksel problem çözme yöntemlerinden temel farkı, çözümü amaçlanan problemi daha geniş bir çerçeve içinde sistematik bir biçimde toplam sistem açısından ele alması ve değerlendirmesidir. 
Yönetim faaliyetlerinin bu yaklaşım çerçevesi içinde incelenmesi :

a) Amaçlann açılklkla ifade edilmesini gerektirecektir.

b) Bütünü oluşturan parçalarn ya da bileşenlerin ve aralarnndaki etkileşimin belirlenmesini sağladığı gibi işletme içinde en duyarlı noktaların saptanmasi ve bu noktalara gerekli dikkatin yoğunlaşmasinı sağlar.

c) Sistem analizi süreci her yinelenmesinde bir karar ile sonuçlanmaktadur. Ancak bu karar çeşitli seçenekler arasından en uygun olanı seçmeden çok sistem etkinliğini anaştırmaya yönelik bir karardir. Bu nedenle işletme faaliyetleri devaml gözetim altında tutulup düzeltilerek daha iyi bir düzenlemeye ve daha etkin bir sistem gelistirilmeye çalışlur.

Etkin bir sistem geliştirme yönetimlerin temel amacı olduguna göre sistem analizi, yönetim için vazgeçilmez bir yardımcı olacaktır.

\section{Özet ve Sonuç}

Sistem kavraminin özünü oluşturan amą, bütünlük ve etkileşim ilkelerine dayalı olarak gelişen sistem yaklaşımı;

a) Insanlarn dünyadaki karmaşık olayları birbiri ile ilişkilendirerek onlardan anlam çıkarmasina yardımcı olan ve bu olayları ayn ayn açıklamaya çalışan bilim alanlanını dünyadaki genel ilişkileri açıklayacak biçimde birleştirmeyi hedefleyen "gent sistem kuramı" ile;

b) Örgütlerin kendilerini oluşturan alt sistemleri amaç, işlev ve etkileşim açısından düzenleme ve yönetiminl ffade eden "sistem yönetimi"ni ve;

c) Yönetim uygulamaları sırasında karşılaşılan sorunlan çözmo ve daha etkin bir sistem geliştirmeye yönelik olan "sistem analizi" kavramlarnı içeren kuramdan uygulamaya ve uygulamada problem çözmeye kadar genelden özele doğru uzanan geniş bir alanı kapsamaktadir.

Sistem yaklaşımının son halkasını oluşturan sistem analiż kavramı yönetim yazınında çoğu kez "sistem çözümleme" olarak dar bir kapsam içinde görülmektedir. Halbuki sistem çözümleme, bir bütünü parçalarına ayırma faaliyeti anlamında, sistem analizinin ilk aşamasıdır. Analiz ya da çözümleme sözcüklerinin belirtmiş olduğu dar anlamı ortadan kaldırmak için Ingilizce yazında sistem analizi kavramunın karşlığı olarak "System Analysis" değil "Systems Analysis" terimi kul- 
lanilır. Böylece, "system" sözcüğünün sonuna bir "s" harfi eklemekle sistem analizi kavramının bir sistem çözümleme faaliyeti değil bir problem çözme ve araştırma yaklaşımı olduğu belirtilmek istenmiştir.

Sistem analizi yazında çoğu kez Yöneylem Araştırması ile aynı görülmektedir. II. Dünya Savaşı sonrası bu terimler aynı anlamda kullanılmıştır. Ancak A.B.D. Savunma Bakanlığında sistem analizi terimi terleşmiştir. Daha sonralan sistem analizi gibi disiplinler arası bir çalışma alanı olan yöneylem araştırması, zamanla matematiksel model ve nicel çözümleme yöntemlerini uygulama becerisi veren bir disiplin haline geldi. Böylece yöneylem araştırmasının giderek dar çerçeveli bir matematiksel beceri alanına dönüşmesi sonucu ve çağımızn karmaşık koşulları içinđe çözüm bekleyen sorunlara cevap bulma arayı̧ı sistem analizinin günümüzde çok yaygınlaşan bir problem çözme yaklaşımı olarak benimsenmesine yol açmıştır.

Öte yandan kimi yazarlar sistem analizi ile maliyet-etkililik (costeffectiveness) ve maliyet-fayda (cost-benefit) analizlerini es anlamlı düşünmektedirler. Aslında bu kavramlar içerik bakımından farklıdırlar. Maliyet-etkililik ve maliyet-fayda analizleri, sistem analizinin, özellikle seçenek değerlendirme aşamasında, en sık kullandığı iki tekniktir. ${ }^{17}$ Ancak kapsamlı bir maliyet-etkililik ya da bir maliyet-fayda analizi bir sistem analizi çerçevesine dönüştürülebilir. Böyle bir durumda da bu analizlerden söz etmek güçleşecektir.

Sistem analizi çalışmalann planlayan ve yöneten uzmanlar olarak sistem analistleri, ülkemizde bilgisayar ve bilgisayara dayalı bilgi işlem sistemlerinin düzenlenmesi ve programlanmasından sorumlu olan bilgisayar uzmanlarn olarak görülmektedir. Sistem analistleri sistem analizi çalışmalarında bilgisayarlardan yoğun bir biçimde yararlanırlar. Çünkü bilgisayar, sistemlerin modelleştirilmesinde, nicel çözümleme yöntemlerinin kullanılmasında ve veri işlemede temel bir araçtır. Bu nedenle sistem analizi çalışmaların yürüten analist bilgisayar kullaniminı yani programlanmasinı bilmek zorunda olmasına karşın, bilgisayar uzmanı olmak zorunda değildir. Bilgisayar mühendisliği ya da uzmanlı̆̆ tamamen teknik bir alandır. Bu alanda uzmanlaşan bireyleri de sistem analisti olarak adlandırmak doğru değildir. Ancak ülkemizde sistem analisti denilince bilgisayar ve bilgi işlem sistemlerinin düzenlenmesini ve yönetimini üstlenen bilgisayar uzmanları anlaşılmaktadır ki bu da doğru bir adlandırma değildir.

18 Hitch, Charles., "An Appreciation of Systems Analysis", in Systems Analysis, S.L Optner, (ed.), (Middlesex : Penguin Books, 1973), s. 20.

17 Black, Guy. The Application of Systems Analysis to Goverment Operations, (New York: Praeger Publishers, 1968), s. 28. 
Daha önceleri belirtildiği gibi sistem analizi daha etkin bir sistem geliştirmek ve yönetimde karşılaşılan sorunları çözmek için yapılması gerekli olan problem çözme ve araştırma çalışmalarının tümünü kapsayan bir araştırma yaklaşımıdır. Bu nedenle de örgütlerde yönetımin vazgeçilmez temel bir yardımcısıdur. Böyle bir problem çözme ve araştırma yaklaşımının daha etkin sistemlerin geliştirilmesinde önemli bir yer tutacağı tartışma götürmeyecek kadar açıktır.

\section{KAYNAKLAR}

1. Bertalanffy, L. von; "The Theory of Open Systems in Physics and Biology" in Systems Thinking, ed. F.E. Emery; (Middlesex: Penguin Books Ltd., 1868).

2. Black, Guy; The Application of Systems Analysis to Government Operations, (New York: Praeger Publishers, 1968).

3. Churchman, West C., The Systems Approach, (New York: Dell Publishing Co., Inc., 1868).

4. Emery, F.E. (ed.); Systems Thinking, (Middlesex : Penguin Books Ltd., 1968).

5. Fisher, Gene H.; Cost Considerations in Systems Analysis, (New York. American Elsevier Publishing Co., Inc., 1971).

6. Hitch, Charles; "Am Appreciation of Systems Analysis" in Systems Analysis, ed. S.L. Optner, (Middlesex : Penguin Book Ltd, 1973).

7. Johnson, R.A., Kast, F.E. and Rosenzweig, J.E.; "Systems Theory and Management", Management Science, vol. 10 (1964).

8. Johnson, R.A., Roger, W.C., and Newell, J.; Operations Management : A Systems Concept, (Boston: Houghton Mifflin Co., 1972).

9. Katz, D. and Kahn, R.L.; "Common Characteristics of Open Systems" in Systems Thinking, ed. F.E. Emery.

10. McMillan, Claude and Gonzalez Richard F.; Systems Analysis: A Computer Approach to Decision Models, third ed., (Homewood, Ill. : Richard D. Irwin, Inc., 1973).

11. Optner, Stanford L.; Systems Analysis for Business Management, (Englewood Cliffs, N.J. : Prentice-Hall, Inc., 1960).

12. Optner, Stanford L. (ed.), Systems Analysis, (Middlesex : Penguin Books, 1973).

13. Quade, E.S. and Boucher, W.I., (eds.); Systems Analysis and Policy Planning. (New York: American Elsevier Publishing Co., Inc., 1968).

14. Rudwich, Bernard H.; Systems Analysis for Effective Planning, (New York: John Wiley and Sons, Inc., 1869).

15. Semprevivo, Philip C., Systems Analysis: Definition, Process and Design. (Chicago: Science Research Associates, Inc., 1976). 